\title{
Chemical Modification of Polystyrene Merrifield: Extraction of Zinc and Magnesium Located in Wastewater
}

\author{
Abid Ouerghui ${ }^{1,2,}$, , Mokhtar Dardouri ${ }^{3}$, Hichem Elamari ${ }^{3}$, Faycel Ammari ${ }^{3}$, Christian Girard $^{1}$ \\ ${ }^{1}$ Department of Chemistry, National Graduate School of Chemistry, Paris Sciences \& Letters - PSL University, Paris, France \\ ${ }^{2}$ Department of Basic Sciences, Higher Institute of Biotechnology of Beja, University of Jendouba, Beja, Tunisia \\ ${ }^{3}$ Departement of Chemistry, Faculty of Sciences of Bizerte, University of Carthage, Bizerte, Tunisia
}

\section{Email address:}

ouerghiabid@gmail.com(A. Ouerghui),dardouri_2009@yahoo.fr(M. Dardouri), hichem.supra@yahoo.fr(H. Elamari), ammari1972@gmail.com (F. Ammari), christian.girard achimieparistech.psl.eu (C. Girard)

${ }^{*}$ Corresponding author

\section{To cite this article:}

Abid Ouerghui, Mokhtar Dardouri, Hichem Elamari, Faycel Ammari, Christian Girard. Chemical Modification of Polystyrene Merrifield: Extraction of Zinc and Magnesium Located in Wastewater. American Journal of Polymer Science and Technology.

Vol. 5, No. 3, 2019, pp. 73-80. doi: 10.11648/j.ajpst.20190503.11

Received: June 26, 2019; Accepted: July 19, 2019; Published: August 6, 2019

\begin{abstract}
In order to remove metals ( $\mathrm{Zn} \& \mathrm{Mg}$ ) located in wastewater, a new series of clickable polystyrene Merrifield grafted with azide and alkynes were synthesized and implicated in this domain. In a first step, we transformed the polystyrene Merrifield into the known Azidomethyl polystyrene, in a second step, a coupling reaction between the Azidomethyl polystyrene and dipropargylamine was realized for the synthesis of a new terminated polystyrene alkyne containing one unit of $(1,4)$-triazole. To increase the length of the chain grafted on the polystyrene Merrifield, several coupling reactions are applied, the main idea of this work was to increase the number of $(1,2,3)$-triazole units of this grafted chain. The click chemistry based on the Huygens's reaction catalyzed by copper (I) was used in this synthesis, the new polymers containing $(1,4)$-disubstituted triazole are tested for the extraction of $\mathrm{Mg}$ and $\mathrm{Zn}$ located in wastewater. The structure of new obtained polymers was confirmed by infrared spectroscopy (ATR-FTIR), UV-visible spectroscopy and elemental analysis for nitrogen. Differential Thermal Analysis (DTA) and Thermo Gravimetric Analysis (TGA) were used to study crosslinking behavior of these polymers. This study shows a low selectivity of studied polymers for the retention of magnesium, while for the Zinc, the percentage removal was average, it's in the order of $30 \%$.
\end{abstract}

Keywords: Polystyrene Merrifield, (1,4)-Triazoles, Extraction, Zinc and Magnesium in Wastewater

\section{Introduction}

Water was an important source of sustainable development, it was used for the fight against poverty, economic growth and environmental sustainability. For this reason, the purification of wastewater was the recent idea in this work. In our day, pollution has become an important problem, because a major part of toxic pollutants was introduced into urban wastewater. Heavy metals (MXn) [1, 2], organic compounds (O. C) [3] and nitrate ions $\left(\mathrm{NO}_{3}^{-}\right)$[4] constituted the major toxic pollutants rejected in urban wastewater. The elimination of these pollutants from the aquatic environment was not usually achieved by natural processes, because these pollutants established between them a stable complexes. Farmers used wastewater in irrigation, because they were rich in nutrients elements [5]. The pollutants located in wastewater can be accumulated in the soil, can be absorbed by plants $[6,7]$, and can be also percolated from groundwater [8]. The toxicity of heavy metals is mainly due to their tendency to accumulate in living organisms and to concentrate along trophic chains [9]. The objective of this work was the synthesis of new polymers containing (1,4)-triazole units from polystyrene Merrifield and testing them in the elimination of $(\mathrm{Zn}$ and $\mathrm{Mg})$ localized in wastewater. The click chemistry based on the Huygens's reaction catalyzed by copper (I) iodide was used in this synthesis [10-14]. Figure 1 summarized the approach of this work. 


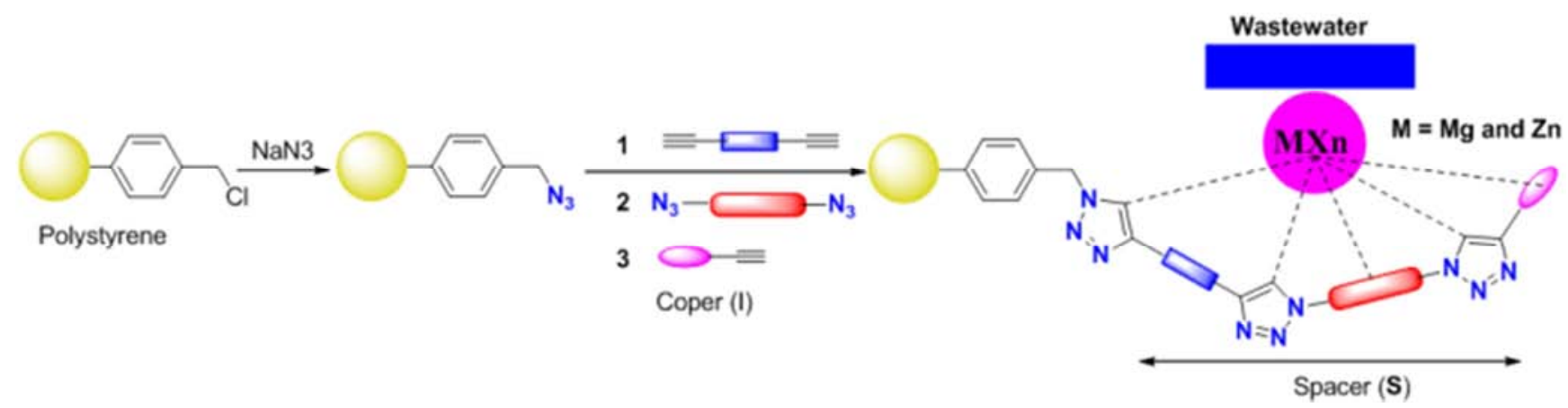

Figure 1. General scheme for synthetic (1,4)-triazoles from Polystyrene Merrifield and its application in extraction of (Zn \&Mg) located in wastewater.

\section{Experimental}

\subsection{Materials}

Merrifield polymer (chloromethylated poly-styrene-co-divinyl-benzene (1\%), 200-400 mesh, 1.1 mmol Cl.g $\left.{ }^{-1}\right)$ was used as-received from Fluka, 1-chloro-2-[2-(2-chloroethoxy) ethoxy] ethane $\left(\mathrm{C}_{6} \mathrm{H}_{12} \mathrm{O}_{2} \mathrm{Cl}_{2}\right.$, $\mathrm{Mw}=187.065 ; 99 \%)$, Quinic acid $\left(\mathrm{C}_{7} \mathrm{H}_{12} \mathrm{O}_{6}, \mathrm{Mw}=\right.$ $\left.192.17 \mathrm{~g} \cdot \mathrm{mol}^{-1}\right)$, propargylamine $\left(\mathrm{C}_{3} \mathrm{H}_{5} \mathrm{~N}, \mathrm{Mw}=55.08 \mathrm{~g} \cdot \mathrm{mol}^{-1}\right.$; $98 \%)$, di-propargyl amine $\left(\mathrm{C}_{6} \mathrm{H}_{7} \mathrm{~N}, \mathrm{Mw}=93.13 \mathrm{~g} \cdot \mathrm{mol}^{-1} ; 97 \%\right)$, copper (I) iodide $(99,5 \%)$, sodium azide $(99 \%)$, sodium sulfate $(99 \%)$, acetone $(97 \%)$, N'N-dimethyl formamide (DMF), diethyl ether (99\%), methylene chloride $\left(\mathrm{CH}_{2} \mathrm{Cl}_{2}\right)$, Tetrahydrofuranne (THF), Dimethyl sulfoxide (DMSO), Methanol $(\mathrm{MeOH})$ and tri-ethylamine $\left(\mathrm{ET}_{3} \mathrm{~N}\right)$ were purchased by Sigma Aldrich. The samples of wastewater were taken from the station of treatment of Beja ( $36^{\circ} 44^{\prime}$ North, $9^{\circ} 11^{\prime}$ East, Tunisia).

The collection of wastewater was taken in the first week of January 2017. The sampling of wastewater was taken by immersing the bottle with $1 \mathrm{~L}$ of capacity in the basin at $15 \mathrm{~cm}$ in depth. The sample was maintained at $4^{\circ} \mathrm{C}$ and filtered before treatment by polymers.

Infrared analysis using the attenuated total reflectance technique (ATR/FTIR) was made on a Nicolet IR 200 FTIR spectrometer between 4000 and $400 \mathrm{~cm}^{-1}$. The relevant absorption bands of vibrations ( $v$ ) was indicated. Elemental analysis of $(\mathrm{N})$ was performed by using Perkin Elmer Analyzer CHN Series II 2400. Nuclear magnetic resonance spectroscopy (NMR) was recorded on a Bruker Avance 300 at $300 \mathrm{MHz}$ for the proton spectra. Differential thermal analysis DTA was performed on a SETARAM TGA92, Thermal Gravimetric Analysis was performed on a Labsys TG. The samples $(10-15 \mathrm{mg})$ were placed in $40 \mu \mathrm{L}$ aluminum pans and analyzed under argon between 25 and $600^{\circ} \mathrm{C}$ at a heating speed of $10^{\circ} \mathrm{C} \cdot \mathrm{min}^{-1}$. The UV-Vis spectra were carried out using UV-Vis spectrophotometer BKUV $1600 \mathrm{PC}$ in the DMF, atomic absorption spectroscopy (AAS) analysis (PerkinElmer A Analyst 200) operating with an air-acetylene flame was used to measure residual metal ion concentrations.

\subsection{Organic Synthesis}

\subsubsection{Synthesis of}

1-azido-2-[2-(2 azidoethoxy)ethoxy]ethane (A)

Sodium azide $(5.85 \mathrm{~g}, 90 \mathrm{mmol})$ was added to a solution of 1-chloro-2-[2-(2-chloroethoxy)ethoxy]ethane (5.61g, $30 \mathrm{mmol}, 33 \%$ ) in $50 \mathrm{~mL}$ of DMF. The reaction mixture was stirred under nitrogen at $80^{\circ} \mathrm{C}$ for $20 \mathrm{~h}$. The resulting product was washed with distilled water $(750 \mathrm{~mL})$ and extracted by diethyl ether $(3 \times 50 \mathrm{~mL})$. The organic phase was washed three times with distilled water $(3 \times 50 \mathrm{~mL})$ for removing unreacted sodium azide, and dried over $\mathrm{MgSO}_{4}$. After filtration, the solvent was evaporated under vacuum. The resulting compound was colorless viscous $(4.18 \mathrm{~g}, 21 \mathrm{mmol}, 70 \%)$ (Figure 2).

${ }^{1} \mathrm{H}$ NMR, $\left(300 \mathrm{MHz}, \mathrm{CDCl}_{3}, \delta\right): 3.63(\mathrm{t}, 4 \mathrm{H}) ; 3.67(\mathrm{t}, 4 \mathrm{H})$; $3.78(\mathrm{t}, 4 \mathrm{H})$.

ATR/FTIR: $2873\left(v_{\mathrm{CH} 2}\right), 2094\left(v_{\mathrm{N} 3}\right), 1288\left(v_{\mathrm{C}-\mathrm{N}}\right) \mathrm{cm}^{-1}$.
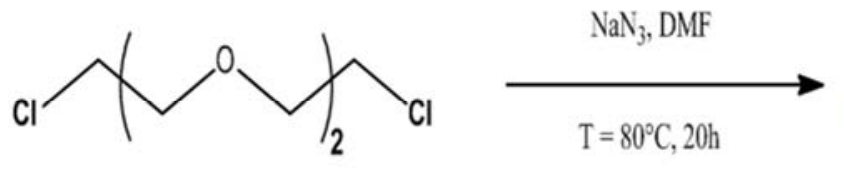

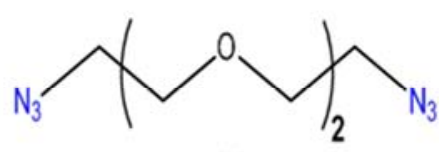

(A)

Figure 2. Reaction scheme of synthesis of 1-azido-2-[2-(2-azidoethoxy)ethoxy]ethane (A).

\subsubsection{Synthesis of (1S, 3R, 5R,}

7R)-5,7-dihydroxy-2,2-diméthyl-N-(prop-2-yn-1-yl) hexahydro-1,3-benzodioxole-5-carboxamide (C)

The alkyne (1S, 3R,

7R)-5,7-dihydroxy-2,2-diméthyl-N-(prop-2-yn-1-yl)
hexahydro-2H-1,3-benzodioxole-5-carboxamide

was prepared using the method taken from the literature [15]. The steps of this synthesis were presented in the Figure 3.

${ }^{1} \mathrm{HNMR}, \mathrm{B}, \mathrm{C}_{10} \mathrm{H}_{15} \mathrm{O}_{5}:\left(300 \mathrm{MHz}, \mathrm{CDCl}_{3}, \delta\right): 1.36(\mathrm{~s}, 3 \mathrm{H})$, 5R, $1.55(\mathrm{~s}, 3 \mathrm{H}), 2.23(\mathrm{~d} . \mathrm{d}, \mathrm{J}=15 \mathrm{~Hz}, \mathrm{~J}=3 \mathrm{~Hz}, 1 \mathrm{H}), 2.40(\mathrm{~m}, 2 \mathrm{H})$, $2.68(\mathrm{dd}, \mathrm{J}=15 \mathrm{~Hz}, \mathrm{~J}=3 \mathrm{~Hz}, 1 \mathrm{H}), 3.71(\mathrm{~s}, 1 \mathrm{H}), 4.31-4.35$ (m, 
$1 \mathrm{H}), 4.51-4.54(\mathrm{~m}, 1 \mathrm{H})$ and $4.72-4.75(\mathrm{~m}, 1 \mathrm{H}) \mathrm{ppm}$.

${ }^{1} \mathrm{HNMR}, \mathrm{C}, \mathrm{C}_{13} \mathrm{H}_{19} \mathrm{NO}_{5}$ : $\left(300 \mathrm{MHz}, \mathrm{CDCl}_{3}, \delta\right): 1.26(\mathrm{~s}, 3 \mathrm{H})$, $1.43(\mathrm{~s}, 3 \mathrm{H}), 1.91-2.30(\mathrm{~m}, 5 \mathrm{H}), 3.41(\mathrm{~s}, 1 \mathrm{H}), 3.86-4.12(\mathrm{~m}$, $4 \mathrm{H}), 4.53-4.55(\mathrm{~m}, 1 \mathrm{H})$ and $7.41(\mathrm{~s}, 1 \mathrm{H}) \mathrm{ppm}$.
ATR/FTIR, B: $2984\left(v_{\mathrm{C}-\mathrm{H}}\right), 1747\left(v_{\mathrm{C}=\mathrm{O}}\right), 1051\left(v_{\mathrm{C}-\mathrm{N}}\right), 1122$ $\left(v_{\mathrm{C}-\mathrm{O}}\right) \mathrm{cm}^{-1}$.

ATR/FTIR, C: $3417\left(v_{\mathrm{O}-\mathrm{H}}\right), 3286\left(v_{\mathrm{NH}}\right), 2985-2928\left(v_{\mathrm{CH}}\right)$, $1653\left(v_{\mathrm{C}=\mathrm{O}}\right), 1043\left(v_{\mathrm{C}-\mathrm{N}}\right) \mathrm{cm}^{-1}$.

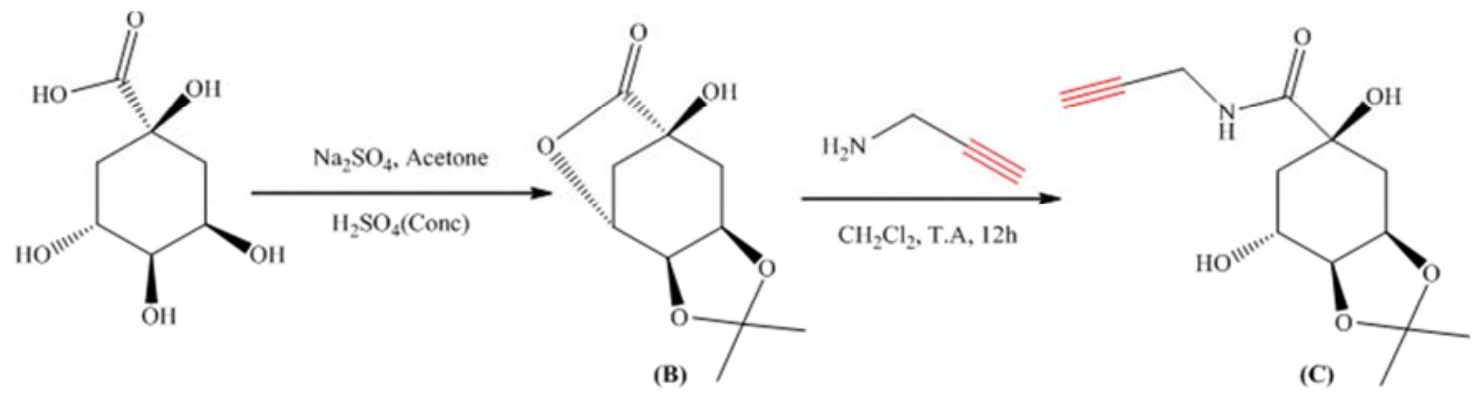

Figure 3. Reaction scheme of synthesis of (1S, 3R, 5R, 7R)-5,7-dihydroxy-2,2-diméthyl-N-(prop-2-yn-1-yl) hexahydro-1,3-benzodioxole-5-carboxamide (C).

\subsubsection{Synthesis of Azidomethyl Polystyrene (D)}

The method of preparation of Azidomethyl polystyrene (D) presented in Figure 4 was described by Ouerghui et al. [16].

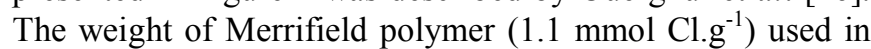
this synthesis was $10 \mathrm{~g}$, the weight of polymer azide obtained was $9.5 \mathrm{~g}$.

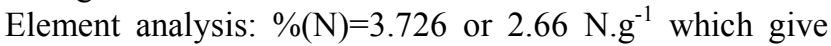
$0.89 \mathrm{mmol} \mathrm{N}_{3} \cdot \mathrm{g}^{-1}$, the yield of the substitution reaction was $81 \%$.

ATR/FTIR: $3034\left(v_{\mathrm{Car}-\mathrm{H}}\right), 2929\left(v_{\mathrm{CH} 2}\right), 2098\left(v_{\mathrm{N} 3}\right), 1022$ $\left(v_{\mathrm{C}-\mathrm{N}}\right) \mathrm{cm}^{-1}$.

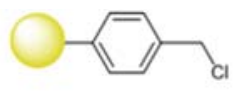

Polystyrene Merrifield

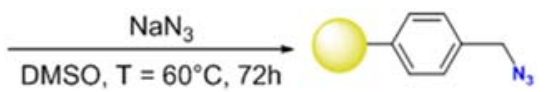

Polymer D
Figure 4. Reaction scheme of synthesis of Azidomethyl polystyrene (D).

\subsubsection{Synthesis of [4-(N-propynylamino}

Methyl)Triazol-1-yl]Methyl Polystyrene (E)

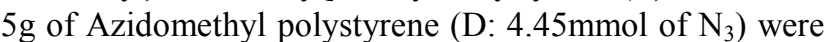
suspended in $85 \mathrm{~mL}$ of THF, after a low agitation for 30 minutes at room temperature, $0.589 \mathrm{~g}$ of di-propargyl-amine $(6,325 \mathrm{mmol}, 1.4 \mathrm{eq}), 0.026 \mathrm{~g}$ of copper iodide ( $0,14 \mathrm{mmol}, 3 \%)$ and $8 \mathrm{~mL}$ of $\mathrm{ET}_{3} \mathrm{~N}(5.81 \mathrm{~g}, 57.5 \mathrm{mmol}, 13 \mathrm{eq})$ were added. The suspension was slowly stirred at $\mathrm{T}=40^{\circ} \mathrm{C}$ for 72 hours, After filtration under vacuum, the obtained polymer was washed three times with THF $(30 \mathrm{~mL}), \mathrm{ET}_{3} \mathrm{~N}(10 \mathrm{~mL})$, methylene chloride $(10 \mathrm{~mL})$ and $\mathrm{MeOH}(10 \mathrm{~mL})$ alternatively and then dried at $40^{\circ} \mathrm{C}$ for 48 hours, the weight of new isolated polymer after purification was $4.28 \mathrm{~g}$ (Elemental analysis: $\%(\mathrm{~N})=4.409)$, The product obtained was a mixture of two polymers (E+E') (Figure 5).

ATR/FTIR: $3379\left(v_{\mathrm{N}-\mathrm{H}}\right), 2990\left(v_{\mathrm{Car}-\mathrm{H}}\right), 2928\left(v_{\mathrm{CH} 2}\right), 2120$ $\left(v_{\mathrm{C} \equiv \mathrm{C}}\right), 1646\left(v_{\mathrm{N}=\mathrm{N}}\right)$ and $1610\left(v_{\mathrm{Car}=\mathrm{Car}}\right) \mathrm{cm}^{-1}$.
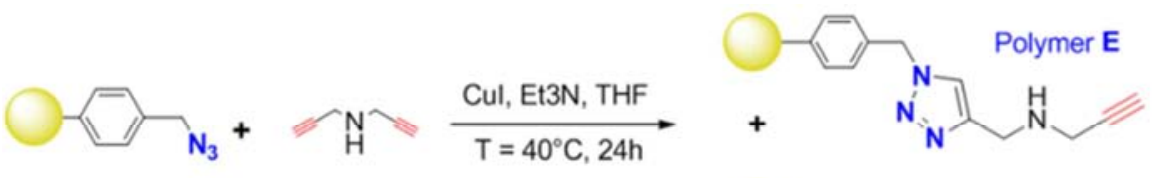

Polymer D

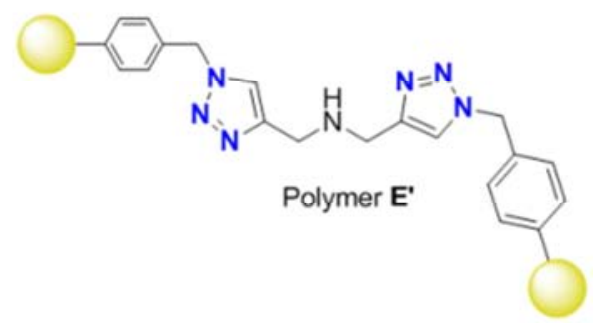

Figure 5. Reaction scheme of synthesis of [4-(N-propynyl amino methyl)triazol-1-yl]methyl polystyrene (E).

\subsubsection{Synthesis of [4-\{2-[2-(2 azidoethoxy)ethoxy]ethyl \}triazol-1-yl-(N,N-dimethyla mino)triazol-1-yl]methyl polystyrene $(F)$}

The method of synthesis of polymer $(F)$ was described in Figure 6 . In $85 \mathrm{~mL}$ of THF, $4 \mathrm{~g}$ of the mixture (E+E') was slowly agitated for $30 \mathrm{~min}$ at room temperature. 1-azido-2-[2-(2-azidoethoxy)ethoxy]ethane (A: $5.4 \mathrm{~g}$, $27 \mathrm{mmol}), \mathrm{CuI}(2 \mathrm{mg}, 0.01 \mathrm{mmol})$ and $\mathrm{Et}_{3} \mathrm{~N}(5 \mathrm{~mL}, 3.63 \mathrm{~g}$ $36 \mathrm{mmol}$ ) have been added. The suspension was slowly stirred at $40^{\circ} \mathrm{C}$ for 72 hours. After filtration under vacuum, the obtained product was washed three times with THF $(10 \mathrm{~mL})$, $\mathrm{ET}_{3} \mathrm{~N}(10 \mathrm{~mL}), \mathrm{CH}_{2} \mathrm{Cl}_{2}(10 \mathrm{~mL})$ and $\mathrm{MeOH}(10 \mathrm{~mL})$ alternatively and finally dried under vacuum at $40^{\circ} \mathrm{C}$ for 48 hours. The obtained product was a mixture of three polymers $\left(\mathrm{F}+\mathrm{E}^{\prime}+\mathrm{F}^{\prime}\right)$, the weight of the mixture of polymers was $3.54 \mathrm{~g}$ (Elemental analysis: \%(N)=4.262).

ATR/FTIR: $3026\left(v_{\mathrm{Car}-\mathrm{H}}\right), 2911\left(v_{\mathrm{CH} 2}\right), 2104\left(v_{\mathrm{N} 3}\right), 1602$ $\left(v_{\mathrm{N}=\mathrm{N}}\right) \mathrm{cm}^{-1}$. 


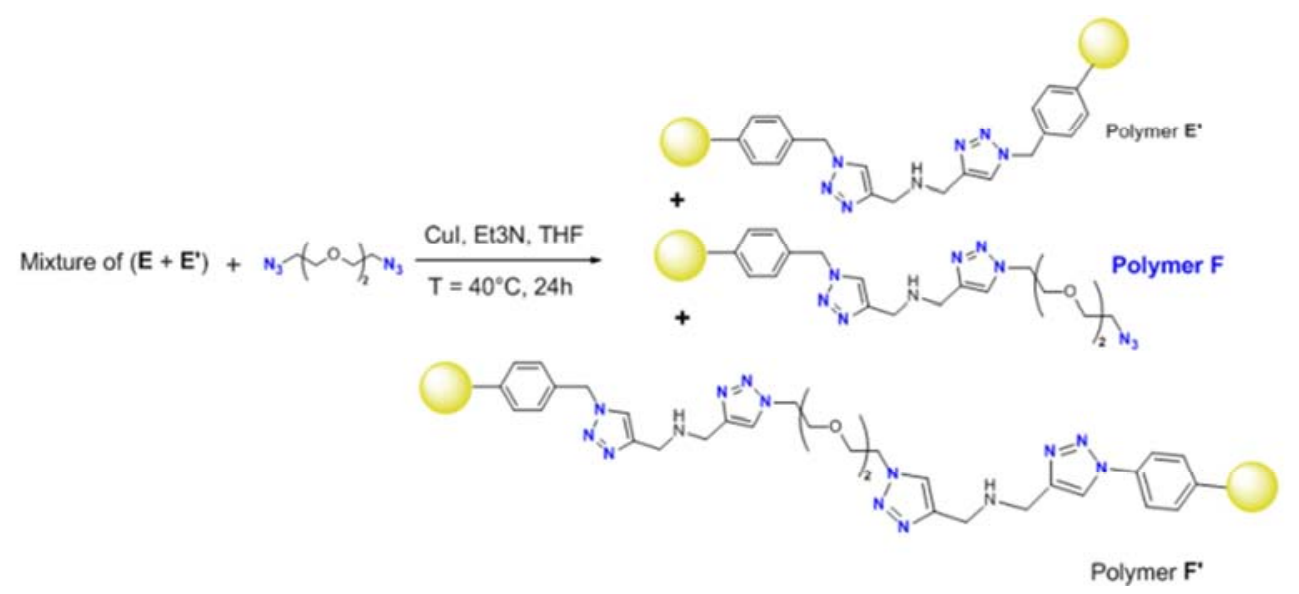

Figure 6. Reaction scheme of synthesis of [4-\{2-[2-(2-azidoethoxy)ethoxy]ethyl\}triazol-1-yl-(N,N-dimethylamino)triazol-1-yl]methyl polystyrene (F).

\subsubsection{Synthesis of}

[4-(2-\{2-2-(4-[(1S,3R,5R,7R)-5,7-dihydroxy-2,2-dimet

hylhexahydro-1,3-benzodioxole-5-carboxamidomethyl Itriazol-1-yl)ethoxy)ethoxy'ethyl)triazol-1-yl-(N,N)-di methylamino)triazol-1-yl]methylpolystyrene (G)

At $1 \mathrm{~g}$ of the polymers $\left(\mathrm{F}^{-}+\mathrm{E}^{\prime}+\mathrm{F}^{\prime}\right)$ in $10 \mathrm{~mL}$ of $\mathrm{DMF}$, we add $1 \mathrm{~g} \quad$ of $\quad(1 \mathrm{~S}, \quad 3 \mathrm{R}$, 5R,7R)-5,7-dihydroxy-2,2-diméthyl-N-(prop-2-yn-1-yl)hexa hydro-1,3-benzodioxole-5-carboxamide (3.71 mmol) (C), $2 \mathrm{mg}$ of cooper iodide $(0.01 \mathrm{mmol})$ and $1.5 \mathrm{~mL}$ of $\mathrm{ET}_{3} \mathrm{~N}(1.22 \mathrm{~g}$,
$12 \mathrm{mmol}$ ), the mixture was stirred at $40^{\circ} \mathrm{C}$ for $24 \mathrm{~h}$. The obtained new product was filtered under vacuum and washed with DMF $(10 \mathrm{~mL}), \mathrm{ET}_{3} \mathrm{~N}(10 \mathrm{~mL}), \mathrm{CH}_{2} \mathrm{Cl}_{2}(10 \mathrm{~mL}), \mathrm{MeOH}$ $(10 \mathrm{~mL})$ three times alternatively and finally washed with distillated water $(150 \mathrm{~mL})$. After drying at $60^{\circ} \mathrm{C}$ for two days under vacuum, the weighted of obtained product was $1 \mathrm{~g}$. The obtained product was a mixture of three polymers $\left(G+E^{\prime}+F^{\prime}\right)$, (Figure 7).

ATR/FTIR: $3450\left(v_{\mathrm{O}-\mathrm{H}}\right), 3034\left(v_{\mathrm{Car}-\mathrm{H}}\right), 2937\left(v_{\mathrm{CH} 2}\right), 1725$ $\left(v_{\mathrm{C}=0}\right), 1602\left(v_{\mathrm{N}=\mathrm{N}}\right) \mathrm{cm}^{-1}$.

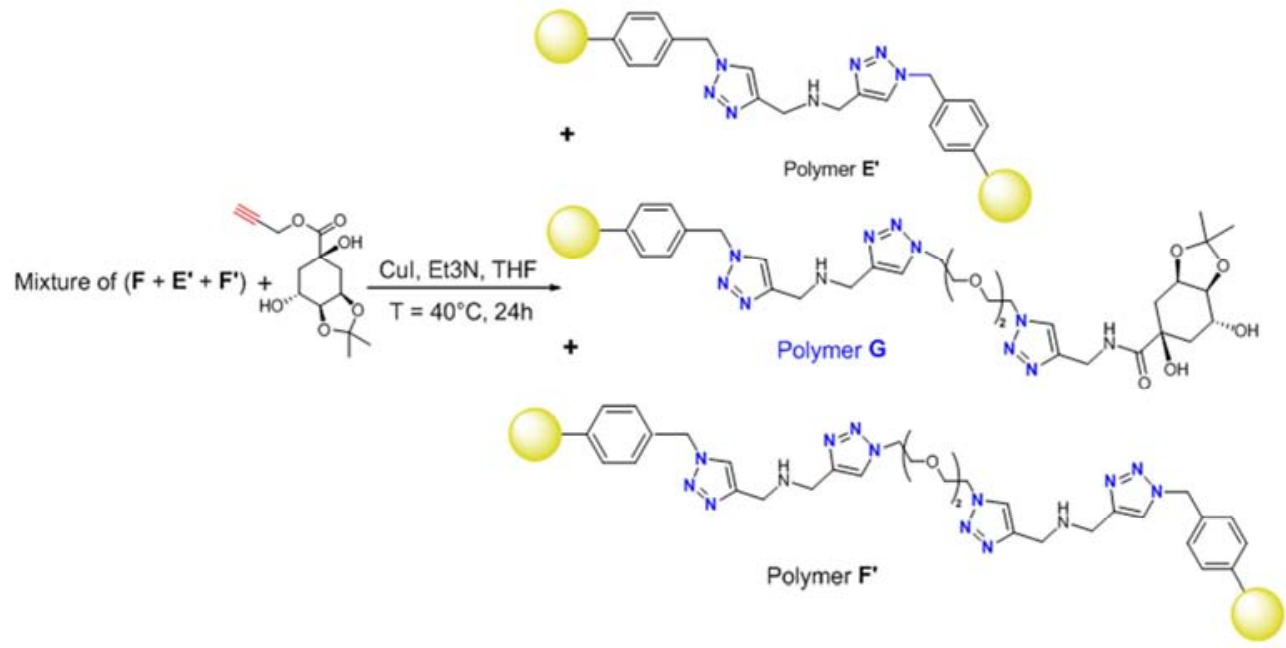

Figure 7. Reaction scheme of synthesis of [4-(2-\{2-2-(4-[(1S,3R,5R,7R)-5,7-dihydroxy-2,2-dimethylhexahydro-1,3-benzodioxole-5-carboxamidomethyl]triazol-1 yl)ethoxy)ethoxy\}ethyl)triazol-1-yl-(N,N)-dimethylamino)triazol-1-yl]methylpolystyrene $(G)$.

\subsubsection{Synthesis of}

[4-\{(IS,3R,5R,7R)-5,7-dihydroxy-2,2-dimethylhexahy dro-1,3-benzodioxole-5-carboxamidomethyl\} triazol-1-yllmethylpolystyrene $(\mathrm{H})$

The polymer $(\mathrm{H})$ presented in Figure 8 was synthesized by the condensation reaction between $1 \mathrm{~g}\left(0.89 \mathrm{mmol} \mathrm{N}_{3}\right)$ of polystyrene azide (D) and (1S, 3R,5R,7R)-5,7-dihydroxy-2,2-diméthyl-N-(prop-2-yn-1-yl)h exahydro-1,3-benzodioxole-5-carboxamide (C) $\quad(0.78 \mathrm{~g}$, $2.78 \mathrm{mmol}, 3.12 \mathrm{eq})$ in presence of copper iodide $(6 \mathrm{mg}$,
$0.03 \mathrm{mmol}, 3.4 \%)$ and $1.5 \mathrm{~mL}$ of $\mathrm{ET}_{3} \mathrm{~N}(1.12 \mathrm{~g}, 11 \mathrm{mmol}, 12.5 \mathrm{eq})$ in $10 \mathrm{~mL}$ of DMF. The suspension was stirred at $40^{\circ} \mathrm{C}$ during 72 hours, after filtration under vacuum, the polymer $(\mathrm{H})$ was washed three times with DMF $(10 \mathrm{~mL}), \mathrm{ET}_{3} \mathrm{~N}(10 \mathrm{~mL}), \mathrm{CH}_{2} \mathrm{Cl}_{2}$ $(10 \mathrm{~mL}), \mathrm{MeOH}(10 \mathrm{~mL})$ alternatively and finally washed with $150 \mathrm{~mL}$ of distillated water, this polymer was dried under vacuum at $60^{\circ} \mathrm{C}$ for two days. The weight of new isolated polymer was $0.9 \mathrm{~g}$, which give the yield $73 \%$.

ATR/FTIR: $3433\left(v_{\mathrm{O}-\mathrm{H}}\right), 3026\left(v_{\text {Car-H }}\right), 2919\left(v_{\mathrm{CH} 2}\right), 1735$ $\left(v_{\mathrm{C}=\mathrm{O}}\right), 1655\left(v_{\mathrm{N}=\mathrm{N}}\right) \mathrm{cm}^{-1}$. 


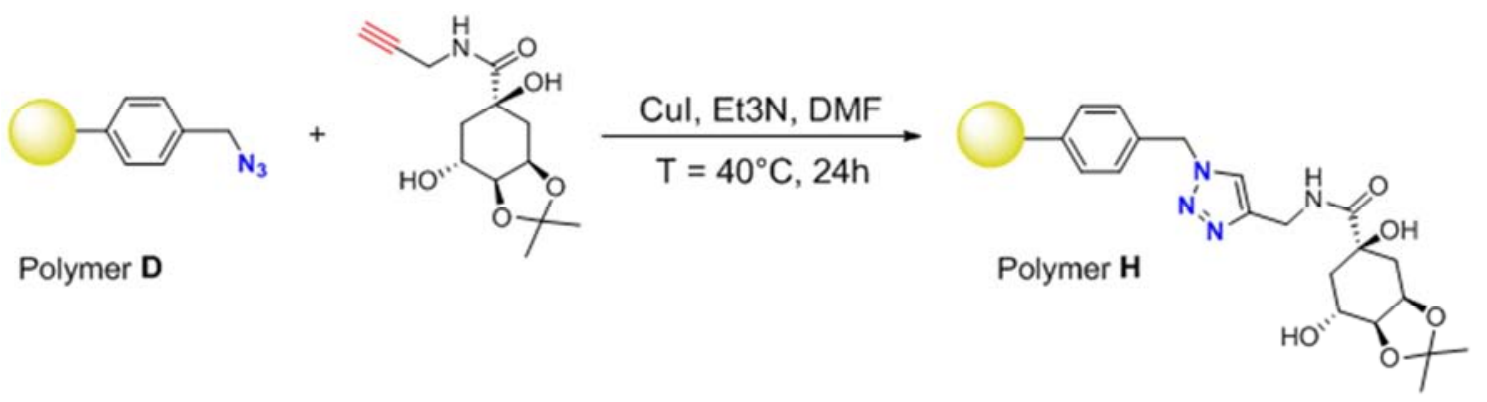

Figure 8. Reaction of synthesis of [4-\{(1S,3R,5R,7R)-5,7-dihydroxy-2,2-dimethylhexahydro-1,3-benzodioxole-5-carboxamidomethyl\}triazol-1-yl]methylpolystyrene $(H)$.

\subsubsection{Extraction of Zn and Mg Metals Located in Wastewater}

The polymers $\left(\mathrm{G}+\mathrm{E}^{\prime}+\mathrm{F}^{\prime}\right.$ \& $\left.\mathrm{H}\right)$ have been studied independently in the elimination of $\mathrm{Zn}$ and $\mathrm{Mg}$ located in wastewater. $0.2 \mathrm{~g}$ of polymer was incubated with $20 \mathrm{~mL}$ of wastewater at room temperature for 48 hours, the suspension was filtrated and washed with distilled water $(5 \times 50 \mathrm{~mL})$, after drying polymers, the solid phase was washed with $50 \mathrm{~mL}$ of distillated water at $\mathrm{T}=50^{\circ} \mathrm{C}$ during $20 \mathrm{mn}$ for desorption of metals ( $\mathrm{Zn} \& \mathrm{Mg}$ ) retained by studied polymers. After filtration, the obtained aqueous phase was analyzed by atomic absorption spectroscopy for dosing the amount of $\mathrm{Zn}$ and $\mathrm{Mg}$ liberated by polymers in distillated water.

\section{Results and Discussion}

Polymers synthesized in this work (Figures 4-8) were evaluated by IR spectroscopy (Figures 9 and 10), Differential Thermal Analysis DTA-TGA (Figure 11 and Table 1) and UV-Visible (Figure 12). Extraction results of $\mathrm{Zn}$ and $\mathrm{Mg}$ were presented in (Figures 13 and 14). Proposed mechanism of $\mathrm{Zn}$ and $\mathrm{Mg}$ extraction by studied polymers was presented in Figure 15.

\subsection{Azidomethyl Polystyrene (D)}

The percentage of nitrogen present in the polymer (D) was $3.726 \%$, which gives $2,66 \mathrm{mmol} \mathrm{N} . \mathrm{g}^{-1}$, for a final substitution of $0.89 \mathrm{mmol} \mathrm{N}_{3} \cdot \mathrm{g}^{-1}$, the yield of the substitution reaction estimated by elemental analysis was in the order of $81 \%$. This substitution reaction was confirmed by IR spectroscopy (Figure 10), the intense band observed at $2095 \mathrm{~cm}^{-1}$ was attributed for the vibrations of group $\mathrm{N}_{3}$.

\section{2. [4-(N-propynyl Amino Methyl)triazol-1-yl]methyl Polystyrene (E)}

The coupling reaction between polymer (D) and di-propargylamine give a mixture of two polymers (E+E'). The proposed structure for (E) was confirmed by IR spectroscopy (Figure 9), but the structure of ( $\left.E^{\prime}\right)$ was similar to that obtained by Sung et al. [17]. The percentage of nitrogen present in $\left(E+E\right.$ ') was $4.409 \%$ or $2.9 \mathrm{mmol}$ of $\mathrm{N}^{-1}{ }^{-1}$. The separation polymers $\left(E+E^{\prime}\right)$ was practically difficult because they are not soluble in organic solvents. The IR spectrum of
$\left(E+E^{\prime}\right)$ presented in (Figure 9) shows a low intensity band at $2120 \mathrm{~cm}^{-1}$ characterizing the vibrations of the alkyne function $(\mathrm{C} \equiv \mathrm{CH})$, disappearance of the band characterizing $\mathrm{N}_{3}$ group observed at $2095 \mathrm{~cm}^{-1}$ in the Figure 10 (Polymer D), and appearance of new bands at 3344 and $1648 \mathrm{~cm}^{-1}$ characterizing respectively the vibrations of $(\mathrm{NH})$ and $(\mathrm{N}=\mathrm{N})$ functions.

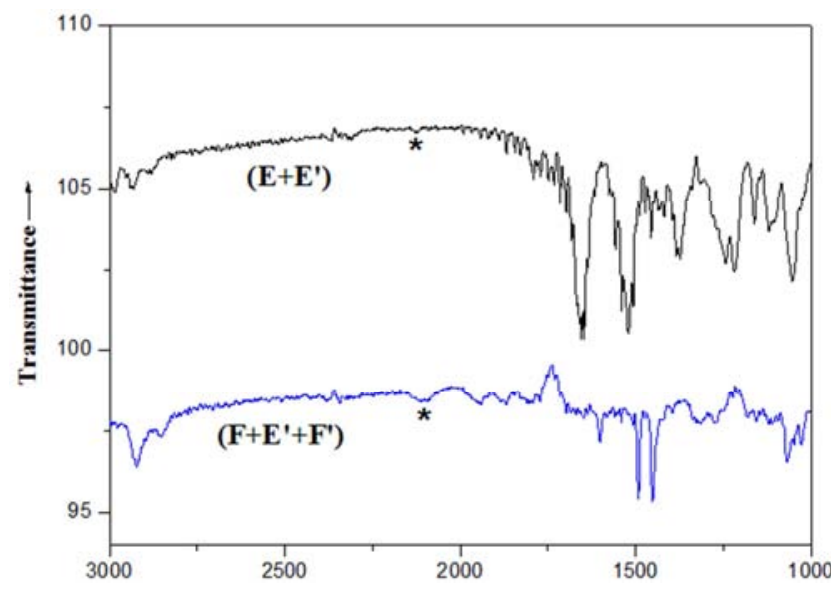

Figure 9. IR spectrum of polymers $\left(E+E^{\prime}\right)$ and $\left(F+E^{\prime}+F^{\prime}\right)$.

\section{3. [4-\{2-[2-(2-azidoethoxy)ethoxy]ethyl\}triazol-1-yl-(N, N-dimethylamino)Triazol-1-yl]Methyl Polystyrene (F)}

The reaction between the mixture of polymers $(E+E$ ') and 1-azido-2-[2-(2-azidoethoxy)ethoxy]ethane (A) gives a mixture of polymers (F+E'+F') (Figure 6). The proposed structure of the polymer $F$ was confirmed by IR spectroscopy presented in Figure 9, the proposed structure of F' was similar to that obtained by Chernykh et al. [18]. The percentage of nitrogen found in this mixture was $4.262 \%$ or $3.04 \mathrm{mmol}$ of $\mathrm{N} \cdot \mathrm{g}^{-1}$. The separation of the polymers (F, E' \& $\mathrm{F}^{\prime}$ ) was practically difficult because they are not soluble in organic solvents.

If we look at the Figure 9, we observe an average band at $2104 \mathrm{~cm}^{-1}$ attributed to the vibrations of $\left(\mathrm{N}_{3}\right)$ group and a strong band observed at $1605 \mathrm{~cm}^{-1}$ attributed to the vibrations of $(\mathrm{N}=\mathrm{N})$ of the triazole heterocyclic, The amount of azide not reacted was low, but the amount of triazole formed was important, which explains the formation of the mixture consisting by the polymers $\left(\mathrm{F}+\mathrm{F}^{\prime}\right)$. Differential Thermal Analysis (DTA) presented in the Figure 11 shows one 
endothermic peak at $412^{\circ} \mathrm{C}$ attributed for the decomposition of the grafted molecule on the Merrifield polystyrene, this decomposition was confirmed by a weight loss $(\Delta \mathrm{m}=$ $-7.88 \mathrm{mg}, \%=78.80)$ observed in the thermo gravimetric curve (Figure 11).

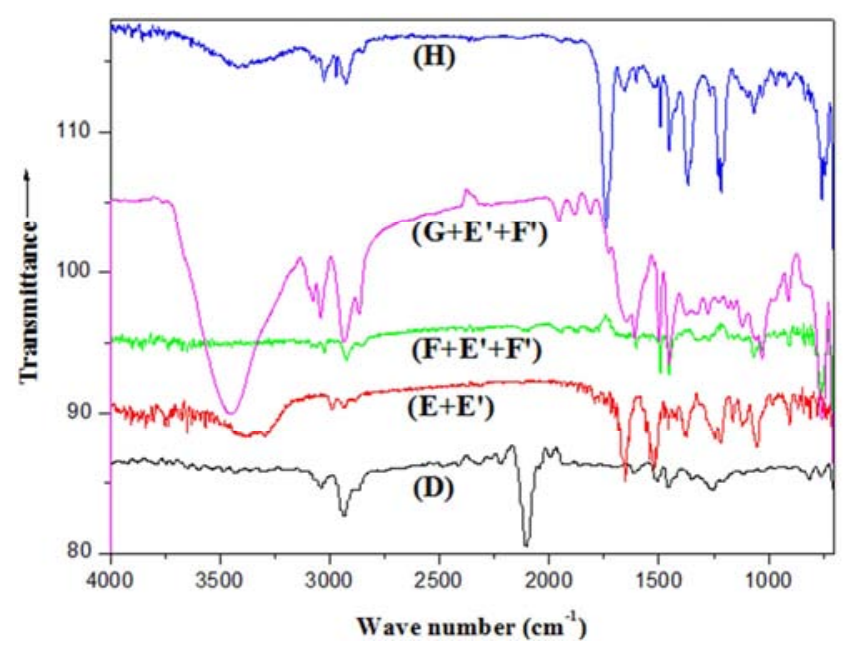

Figure 10. IR spectrum of synthesized polymers $D$ to $H$.

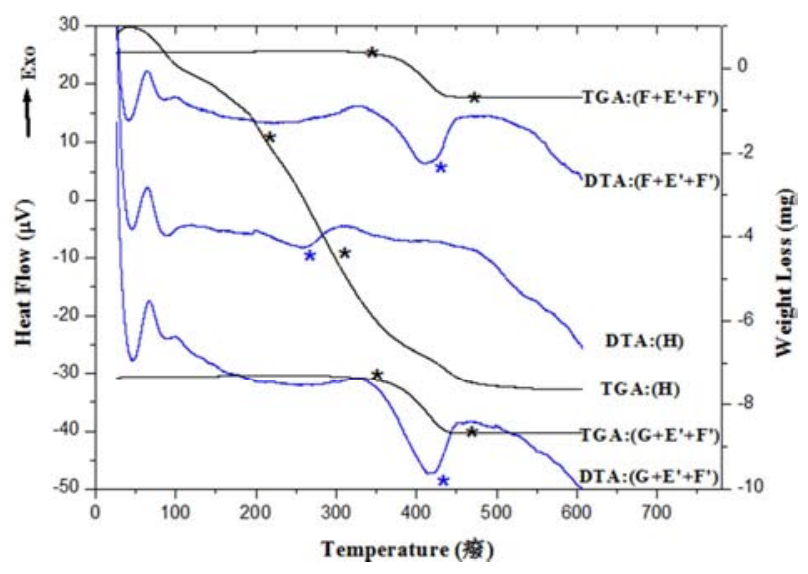

Figure 11. DTA-TGA curves for polymers D to H.

\section{4. [4-(2-\{2-2-(4-I(1S,3R,5R,7R)-5,7-dihydroxy-2,2-dimet hylhexahydro-1,3-benzodioxole-5-carboxamidomethyl]t riazol-1-yl)etoxy)ethoxy\}ethyl)triazol-1-yl-(N,N)-dimeth ylamino)triazol-1-yl]methylpolystyrene $(G)$}

The coupled reaction between the alkyne (1S, 3R,5R,7R)-5,7-dihydroxy-2,2-diméthyl-N-(prop-2-yn-1-yl) hexahydro-1,3-benzodioxole-5-carboxamide (E) and polymers $\left(F+E^{\prime}+F^{\prime}\right)$, give the mixture of polymers $\left(G^{\prime}+E^{\prime}+F^{\prime}\right)$. The polymer (G) was confirmed by IR spectroscopy. IR spectrum presented in Figure 10 shows the disappearance of the band $\left(\mathrm{N}_{3}\right)$ observed at $2104 \mathrm{~cm}^{-1}$ (Figure 9), the appearance of new bands at 3400,1750 and $1605 \mathrm{~cm}^{-1}$ attributed to the vibration of $(\mathrm{OH}),(\mathrm{C}=\mathrm{O})$ and $(\mathrm{N}=\mathrm{N})$, respectively.

Differential Thermal Analysis (DTA) and thermo gravimetric (TGA) presented in (Figure 11) shows an endothermic peak observed at $414^{\circ} \mathrm{C}$ attributed to its decomposition, this decomposition was accompanied by a weight loss $(\Delta \mathrm{m}=-9.67 \mathrm{mg}, \%=77.34)$ (Figure 11).

\section{5. [4-\{(1S,3R,5R,7R)-5,7-dihydroxy-2,2-dimethylhexahy dro-1,3-benzodioxole-5-carboxamidomethyl\}triazol-1-yl Jmethylpolystyrene $(\mathrm{H})$}

The coupled reaction between the alkyne (1S, 3R, 5R, 7R)-5,7-dihydroxy-2,2-diméthyl-N-(prop-2-yn-1-yl)hexahydr o-1,3-benzodioxole-5-carboxamide (E) and polymer (D) catalyzed by cooper iodide give the polymer $(\mathrm{H})$, structure of this polymer was confirmed by IR spectroscopy and thermal analysis (DTA-TGA). If we look at the IR spectrum (Figure $10)$, we observe the existence of characteristic bands at 3446 , 1732 and $1651 \mathrm{~cm}-1$ characterizing the vibrations of $(\mathrm{OH})$, $(\mathrm{C}=\mathrm{O})$ and $(\mathrm{N}=\mathrm{N})$ groups, respectively. On the other hand, we observed the disappearance band of the $\mathrm{N}_{3}$ function.

The DTA-TGA curves of the polymer $(\mathrm{H})$ presented in Figure 11 show an endothermic peak at $256^{\circ} \mathrm{C}$ accompanied by a lost mass $\Delta \mathrm{m}=-3.73 \mathrm{mg}(\%=-25.73)$. This lost mass corresponds to the decomposition of the organic molecule grafted on the polystyrene Merrifield, this results are consistent with these obtained from elemental analysis $\left(0.89 \mathrm{mmol} \mathrm{N}_{3} \cdot \mathrm{g}^{-1}\right)$.

The Figure 12 present the UV-Vis spectra of the synthesized polymers realized in DMF, these results show the existence of an intense peak at $270 \mathrm{~nm}$ attributed for the transition $\left(\pi \rightarrow \pi^{*}\right)$, the polymer $(\mathrm{H})$ present a second transition $\left(\mathrm{n} \rightarrow \pi^{*}\right)$ observed at $310 \mathrm{~nm}$, this transition was absent in the other polymers because their solubility in DMF was low. Results of UV-Vis spectroscopy are consistent with those found by Samanta et al. [19], which proves that synthesized polymers may fall in the category of semiconductors.

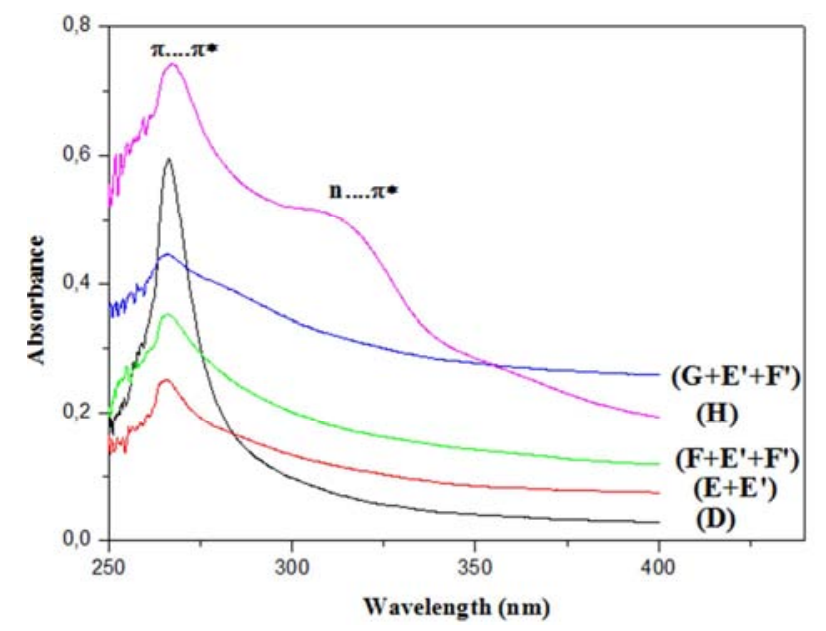

Figure 12. UV absorption spectra of polymers $D$ to $H$ realized in DMF solvent.

\subsection{Extraction of Zn and Mg by Synthesized Polymers}

We present in Figure 13 the percentage of extraction of $\mathrm{Zn}$ and $\mathrm{Mg}$ by polymers $\left(\mathrm{G}^{+} \mathrm{E}^{\prime}+\mathrm{F}^{\prime}\right)$ and $(\mathrm{H}), \mathrm{pH}$ results of wastewater treated by $\left(\mathrm{G}^{+} \mathrm{E}^{\prime}+\mathrm{F}^{\prime}\right)$ and $(\mathrm{H})$ are shown in Figure 14. 
Table 1. DTA and TGA studies of synthesized polymers from polystyrene.

\begin{tabular}{|c|c|c|c|c|c|}
\hline Polymer & $\begin{array}{c}\text { Initial } \\
\text { mass (mg) }\end{array}$ & $\begin{array}{l}\mathbf{T}_{\text {endo }} \\
\left({ }^{\circ} \mathrm{C}\right)\end{array}$ & $\underset{\left({ }_{\left(J . g^{-1}\right)}^{\Delta H}\right.}{ }$ & $\Delta \mathrm{m}(\mathrm{mg})$ & $\%(\Delta \mathrm{m})$ \\
\hline$\overline{F+E^{\prime}+F^{\prime}}$ & 10 & 412 & 575.20 & $\begin{array}{l}-7.88 \\
\end{array}$ & -78.80 \\
\hline $\mathrm{G}^{\prime}+\mathrm{E}^{\prime}+\mathrm{F}^{\prime}$ & 12.5 & 414 & 579.76 & -9.67 & -77.36 \\
\hline $\mathrm{H}$ & 14 & 256 & 143.07 & -3.732 & -26.65 \\
\hline
\end{tabular}

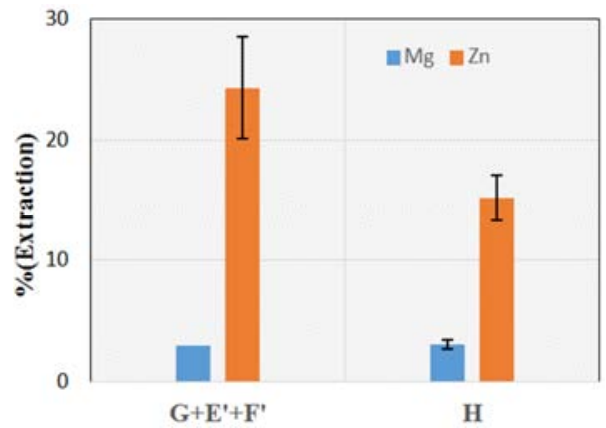

Figure 13. \% (Extraction) of Zn and Mg obtained after treatment wastewater by $\left(G+E^{\prime}+F^{\prime}\right)$ and $(H)$.

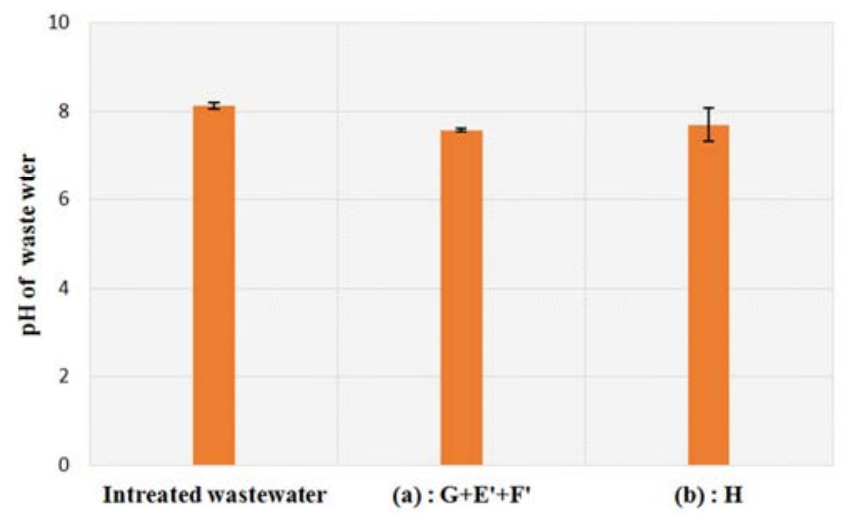

Figure 14. Ph of wastewater before and after treatment (a) by $\left(G+E^{\prime}+F^{\prime}\right)$ and (b) by $(H)$.

The concentrations of metals located in waste water of Beja station (Tunisia) before treatment by studied polymers were presented in Table 2.
Table 2. Concentration of metals localized in untreated wastewater of Beja station.

\begin{tabular}{crcccc}
\hline Metal & $\mathbf{M g}$ & $\mathbf{C u}$ & $\mathbf{F e}$ & $\mathbf{M n}$ & $\mathbf{Z n}$ \\
\hline Concentration $\left(\mathrm{mg} . \mathrm{L}^{-1}\right)$ & 17.45 & 0.01 & 0.061 & $5.10^{-3}$ & 0.175 \\
\hline
\end{tabular}

If we look at the Figure 13, we find that the polymers $\left(G+E^{\prime}+F^{\prime}\right)$ and $(H)$ gave practically the similar percentages of extraction for $\mathrm{Mg}$, the average percentage was $2.92 \pm 0.20$. In this case, neither spacer (S) presented in Figure 1 nor grafted quinic acid derivative have any effect in the extraction of $\mathrm{Mg}$. The polymers studied have no remarkable selectivity for the extraction of Mg.

On the other hand, the best removal percentage Zinc was obtained by the polymer $\left(\mathrm{G}+\mathrm{E}^{\prime}+\mathrm{F}^{\prime}\right)$, the value found was in order of $24.31 \pm 4.17 \%$. The extraction percentage of $\mathrm{Zn}$ by $\left(\mathrm{G}^{\prime}+\mathrm{E}^{\prime}+\mathrm{F}^{\prime}\right)$ was better than those found in the literature [20, 21]. Polymer $(\mathrm{H})$ gave a lower percentage than that obtained using $\left(\mathrm{G}^{+}+\mathrm{E}^{\prime}+\mathrm{F}^{\prime}\right)$, it's in the order of $15.20 \pm 1.86 \%$.

If we compare the structures of polymers $\left(\mathrm{G}+\mathrm{E}^{\prime}+\mathrm{F}^{\prime}\right)$ and $(\mathrm{H})$, we find that the terminal molecule of quinic acid was common for the two polymers, but the spacer $(\mathrm{S})$ shown in Figure 1 was present only in $\left(G+E^{\prime}+F^{\prime}\right)$ and not in $(H)$. The spacer ( $\mathrm{S}$ ) is responsible for the extraction of $\mathrm{Zn}$, but the derivative of quinic acid has no effect on the extraction of metals because the oxygen atoms of quinic acid derivative are distant (Figure 15).

The $\mathrm{pH}$ of intreated and treated wastewater by polymers $\left(\mathrm{G}^{\prime}+\mathrm{E}^{\prime}+\mathrm{F}^{\prime}\right)$ and $(\mathrm{H})$ synthesized from polystyrene are presented in Figure 14. The $\mathrm{pH}$ of the intreated wastewater was about of 8.15 . After treatment by polymers $\left(G+E^{\prime}+F^{\prime}\right)$ and $(\mathrm{H})$, the $\mathrm{pH}$ decreases, the $\mathrm{pH}$ values for treated wastewater by $\left(\mathrm{G}^{+} \mathrm{E}^{\prime}+\mathrm{F}^{\prime}\right)$ and $(\mathrm{H})$ obtained are 7.58 and 7.71 respectively. This decrease in $\mathrm{pH}$ can be explained by the extraction of several basic chemical species: nitrates, sulphates, phosphates and amines [22-24] or by exchange of $\mathrm{H}^{+}$ions of quinic acid derivative with other cations [25].

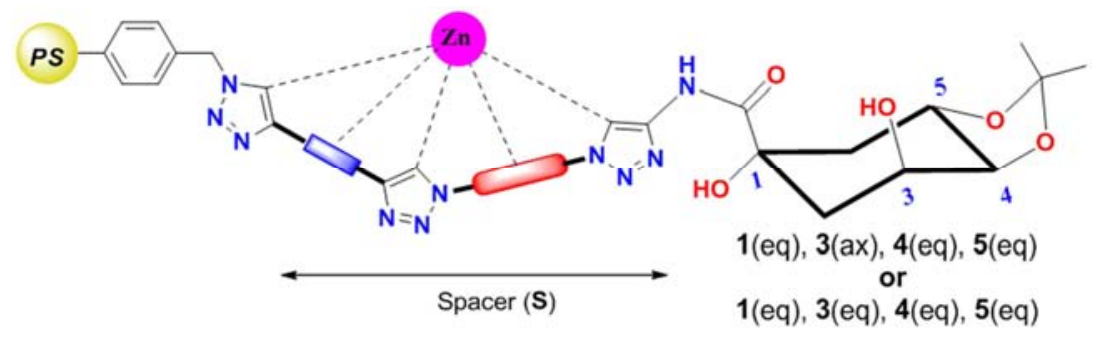

Figure 15. Proposed mechanism for Zn extraction by synthesized polymers.

\section{Conclusion}

In this work, we have synthesized a new compounds from Merrifield polystyrene. These obtained compounds are a mixture of polymers containing $(1,2,3)$-triazole units. The separation of these polymers was practically impossible because they are not soluble in organic solvents. These polymers have been characterized by IR spectroscopy and thermal analysis (DTA \& TGA). These polymers have been tested in the extraction of $\mathrm{Zn}$ and $\mathrm{Mg}$ located in wastewater from Beja region (Tunisia). The obtained polymers do not have a selectivity for $\mathrm{Mg}$, the percentage of extraction obtained did not exceed 3\%. For Zn, the percentage obtained is $25 \%$ with the polymer $\left(\mathrm{G}^{+}+\mathrm{E}^{\prime}+\mathrm{F}^{\prime}\right)$. The percentage of extraction metals was low because other elements (nitrates, sulphates, phosphates and amines) have been removed by these polymers. 


\section{Acknowledgements}

This project is funded by Tunisian (University of Jendouba) and French Grants UMR 8151 CNRS / U1022 INSERM.

\section{References}

[1] Kao, T.; El Mejahed, K. and Bouzidi, A. "Evaluation de la pollution métallique dans les sols agricoles irrigués par les eaux usées de la ville de Settat (Maroc)", Bulletin de l'Institut Scientifique, Rabat, section Sciences de la Vie, 29, 2007, 89-92.

[2] Onivogui, G.; Balde, S.; Bangoura, K. and Barry, M. K. "Évaluation des risques de pollution en métaux lourds $(\mathrm{Hg}, \mathrm{Cd}, \mathrm{Pb}$, $\mathrm{Co}, \mathrm{Ni}, \mathrm{Zn})$ des eaux et des sédiments de l'estuaire du fleuve Konkouré (Rep. de Guinée)"Afrique Sci., 09 (3), 2013, 36-44.

[3] Margot, J.; and Magnet, A. "Elimination des micropolluants dans les eaux usées"Gas Wasser Abwasser (GWA), 7, 2011, 487-493.

[4] Paugam, L.; Taha, S.; Cabon, J.; Gondrexon, N. and Dorange, G. "Nanofiltration of ammonium nitrate solutions. Study of influent parameters" Rev. Sci. Eau, 14 (4), 2001, 511-523.

[5] Hannachi, A.; Gharzouli, R. and Dlellouli Tabet, Y. "Gestion et valorization des eaux usées en Algérie" Larhyss Journal, 19, 2014, 51-62.

[6] Kissao, G.; Koffi, T.; Aléodjrodo, P. E.; Hazou, A.; Koffi, A.; Komi, A.; Gnon, B.; Gado, T.; Koffi, K.; Philippe, B. and Koffi, A. "Bioaccumulation de certains éléments métalliques dans les produits maraîchers cultivés sur les sols urbains le long de l'autoroute Lomé- Aného, Sud Togo" Acta Bot. Gallica, 155 (3), 2008, 415-426.

[7] Hana Sbartai, H.; Med Reda Djebar, M. R.; Ibtissem Sbartai, I. and Houria Berrabbah, H. "Bioaccumulation du $\mathrm{Cd}$ et du $\mathrm{Zn}$ chez les plants de tomates (Lycopersicon esculentum L.)" C. R. Biologies, 335, 2012, 585-593.

[8] Jaouad El Asslouj, J.; Kholtei, S.; Namira El Amrani, N. and Hilali, A. "Analyse de la qualité physico-chimique des eaux souterraines de la communauté des Mzamza, au voisinage des eaux usées” Afrique Science, 03 (1), 2007, 109-122.

[9] Bouchouata, A.; Hanae Ouadarri, H.; Abdallah Abidi, A.; Asmae Benabbou, A.; ENABBOU, Youssef EL Guamr, Y. and Benaïssa Attar, B. "L'accumulation des métaux lourds au niveau des cultures: cas des cultures maraîchères du bassin de Sebou au Maroc" Afrique Science, 08 (2), 2012, 08 (2), 57-75.

[10] Huang, K. W. and Kuo, S. W. "High - Heteronucleobase Content Polystyrene Copolymers Prepared Using Click Chemistry Form Supramolecular Structures With Melamine Through Complementary Multiple Hydrogen - Bonding Interactions" Macromol. Chem. Phys., 213, 2012, 1509-1519.

[11] Tengiz, K.; Temur, K.; Giorgi, T.; Giuli, O.; Nino, K.; Nino, Z.; David, T. and Ramaz, K. "New 1,2,3-Triazole Containing Polyesters via Click Step-Growth Polymerization and Nanoparticles Made of Them" International Journal of Polymer Science, 2018, 1-14.

[12] Fournier, D.; Hoogenboom, R. and Schubert, U. S. "Clicking polymers: a straightforward approach to novel macromolecular architectures" Chem. Soc., 36, 2007, 1369-1380.

[13] Rengifo, H. R.; Grigoras, C.; Dach, B. I.; Li, X., Turro, N. J.;
Lee, H. J.; Wu, W. L. and Koberstein, J. T. "Solid Phase Synthesis of Polymacromer and Copolymacromer Brushes" Macromol., 45, 2012, 3866-3873.

[14] Sood, R.; Zhang, B.; Serghei, A.; Bernarda, J. and Drockenmuller, E. "Triethylene glycol-based poly (1,2,3-triazolium acrylate)s with enhanced ionic conductivity" Polym. Chem., 6, 2015, 3521-3528.

[15] Baptistella, L. H. B. and Cercharo, G."Studies for the transformation of carbocycles into carbohydrates: approach toward the synthesis of higher sugar derivatives" Carbohydrate Res., 339, 2004, 665.

[16] Ouerghui, A.; Elamari, H.; Ghammouri, S.; Slimi, R.; Meganem, F. and Girard, C., "Polystyrene-supported triazoles for metal ions extraction: Synthesis and evaluation" React. Funct. Polym., 74, 2014, 37-45.

[17] Sung, S. R.; Han, S. C.; Jin, S. H. and Lee, J. W. "Convergent Synthesis and Characterization of Dumbbell Type Dendritic Materials by Click Chemistry" Bull Korean Chem. Soc., 32, 2011, 3933-3940.

[18] Chernykh, A.; Agag, T. and Ishida, H. "Synthesis of linear polymers containing benzoxazine moieties in the main chain with high molecular design versatility via click reaction" Polymer, 50, 2009, 382-390.

[19] Samanta, D.; Murugan, P.; Ananthakrishnan, S. J.; Somanathan, N.; Das, N. S. K.; Jaisankar, S. N. and Mandal, A. B. "“"Click” polymerization on a self-assembled monolayer: a convenient approach to functionalize various surfaces with polytriazoles" Chem. Commun., 48, 2012, 12068-12070.

[20] Slimi, R.; Ben Othman, R.; Sleimi, N.; Ouerghui, A. and Girard, G. "Synthesis and Characterization of Polystyrene-Supported Piperazine-Substituted Triazoles by $\mathrm{CuAAC}$ and First Evaluation for Metal Ion Extraction" Polymers, 8, 2016, 187-199.

[21] Taouil, H.; Ibn Ahmed, S.; Rifi, E. and El Assyry, A. "Zinc extraction from dilute aqueous solutions, by hydrogels of polyacrylic acid-polyacrylate sodium (Extraction du zinc à partir des solutions aqueuses diluées, par d'hydrogels d'acide polyacrylique-polyacrylate de sodium” J. Mater Environ Sci., 5, 2014, 1069-1074.

[22] Houssine, S.; Andreas, M.; Uxua Perez de L.; Numa, P.; Philippe, T. and Tanja Z. "Cationic cellulose nanofibers from waste pulp residues and their nitrate, fluoride, sulphate and phosphate adsorption properties" Carbohydrate Polymers, 135, 2016, 334-340.

[23] Fulya, O".; Pınar, A. K. and Olgun, G. "Removal of Phosphate by Using Copper-Loaded Poly (Nvinylimidazole) Hydrogels as Polymeric Ligand Exchanger" Journal of Applied Polymer Science, 119, 2011, 613-619.

[24] Ouerghui, A.; Dardouri, M.; 2), Sleimimi, N.; Bel Hadj Amor, A.; Ammari, F. and Girard, C. "Synthesis of new polymers containing 1,2,3-triazole units from poly (vinyl chloride) via "click" chemistry catalyzed by copper iodide and its application in extraction of nitrates and metals contained in wastewater" Polimery, 64 (1), 2019, 3-11.

[25] Ferrah, N.; Abderrahim, O.; Didi, M. A. and Villemin, D. "Removal of Copper Ions from Aqueous Solutions by a New Sorbent: Polyethyleneiminemethylene Phosphonic Acid" Desalination, 269, 2011, 17-24. 